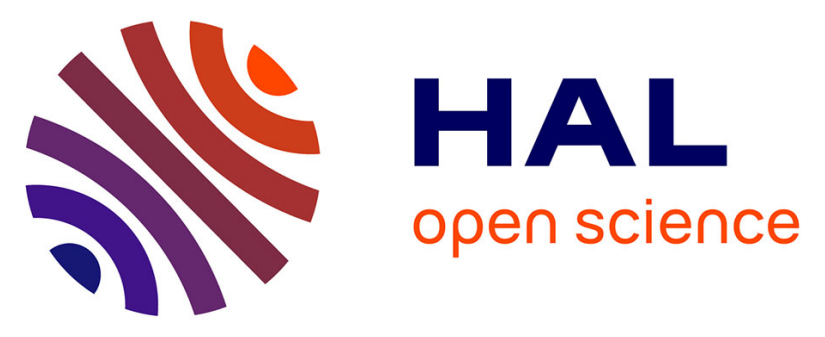

\title{
Investigating the Potential of Delivering Employer Information Requirements in BIM Enabled Construction Projects in Qatar
}

\author{
Mian Atif Hafeez, Racha Chahrour, Vladimir Vukovic, Nashwan Dawood, \\ Mohamad Kassem
}

\section{To cite this version:}

Mian Atif Hafeez, Racha Chahrour, Vladimir Vukovic, Nashwan Dawood, Mohamad Kassem. Investigating the Potential of Delivering Employer Information Requirements in BIM Enabled Construction Projects in Qatar. 12th IFIP International Conference on Product Lifecycle Management (PLM), Oct 2015, Doha, Qatar. pp.159-172, 10.1007/978-3-319-33111-9_15 . hal-01377440

\author{
HAL Id: hal-01377440 \\ https://hal.inria.fr/hal-01377440
}

Submitted on 7 Oct 2016

HAL is a multi-disciplinary open access archive for the deposit and dissemination of scientific research documents, whether they are published or not. The documents may come from teaching and research institutions in France or abroad, or from public or private research centers.
L'archive ouverte pluridisciplinaire HAL, est destinée au dépôt et à la diffusion de documents scientifiques de niveau recherche, publiés ou non, émanant des établissements d'enseignement et de recherche français ou étrangers, des laboratoires publics ou privés. 


\title{
Investigating the potential of delivering Employer Information Requirements in BIM enabled Construction Projects in Qatar
}

\author{
Mian Atif Hafeez ${ }^{1}$, Racha Chahrour ${ }^{2}$, Vladimir Vukovic ${ }^{3}$, Nashwan Dawood ${ }^{3}$, \\ Mohamad Kassem ${ }^{3}$ \\ ${ }^{1}$ Qatar University, Doha, Qatar \\ atifhafeez@qu.edu.qa \\ ${ }^{2}$ HOCHTIEF ViCon Qatar W.L.L, Doha, Qatar \\ Racha.Chahrour@hochtief.de \\ ${ }^{3}$ Teesside University, United Kingdom \\ V.Vukovic@tees.ac.uk \\ N.N.Dawood@tees.ac.uk \\ M.Kassem@tees.ac.uk
}

\begin{abstract}
Employer's Information Requirements (EIR) is a key document for the successful delivery of construction projects using Building Information Modeling (BIM). EIR sets out the information to be delivered and the standards and processes to be adopted by the suppliers as part of their project delivery approach. The concept of EIR has been developed by the UK BIM Task Group as a holistic framework for the UK construction industry to deliver the UK construction client requirements in projects using BIM. It includes a set of requirements and guidelines in three macro areas namely, technical, management and commercial. EIR, which are specific to the construction industry in Qatar, do not exist yet despite BIM is increasingly adopted across the Qatari construction industry. However, construction projects using BIM in Qatar adopts various aspects in technical, management and commercial areas. In this paper, we analyze the current BIM practice in Qatar and compare the findings against the items of the three EIR's areas. The overarching aim is to assess the potential of delivering EIR in BIM based construction projects in Qatar. To accomplish this aim, major construction industry players (clients, consultants, contractors), representing a significant part of Qatar construction industry, were interviewed about the three EIR's areas and their items. The results showed discrepancies in addressing EIR and varied levels of readiness in delivering the different EIR's areas and items. The paper has proposed general guidelines for delivering EIR in Qatar which are informed by the survey and current international EIR standards.
\end{abstract}

Keywords: BIM, EIR, Information Requirements, lifecycle information flow 


\section{Introduction}

Employer Information Requirements (EIR), a terminology developed by the UK BIM Task Group, is a "pre-tender document setting out the information to be delivered, and the standards and processes to be adopted by the supplier as part of the project delivery process" [1]. The UK's Publicly Available Standard (PAS 1192) series makes distinction between a 'Client' and an 'Employer'. A client may appoint an employer who is the legal entity named in the contract and responsible for procuring the asset [1].

The client is considered to be a body which incorporates the interests of the buyer of construction services, prospective users and other interest groups [2]. The client's decision to commission a project is influenced by organizational factors (e.g. strategic, operational, etc.) that add complexity to the process of defining the requirements of the design phase and other project delivery phases [3]. Additional project related requirements are related to site selection, environmental considerations, regulatory framework, design specifications, construction process and life cycle performance [2]. The multidisciplinary and fragmented nature of contracted organizations makes it also difficult for project stakeholders to work towards a consistent understanding of client's requirements.

The adoption of Building Information Modeling (BIM) concepts and workflows is proliferating within organizations, through project teams, and across the whole construction industry [4]. Strategic steps are taken by various governments including UK, Singapore, Finland, USA, among others to encourage the adoption of BIM in their respective AECO industries [5]. Client's requirements should be processed and communicated properly to all project stakeholders throughout the whole project life cycle from the early initiation phase to the handover and operation. Building Information Modeling (BIM) can be a means for project stakeholders to communicate, manage and deliver client's requirements. However, this requires the clear definition of the EIR that sets the processes and standards to be adopted by the suppliers throughout the project life cycle.

While there are no explicit guidelines for defining EIR in Qatar, BIM is increasingly adopted on construction projects. This paper aims to analyze the current BIM adoption in Qatar against the EIR's areas and their items as defined by the UK BIM Task Group. The content outline of the EIR covers three areas and their items include: technical (specification of software platforms, and definitions of levels of detail), management (management processes to be adopted in connection with BIM on a project) and commercial (BIModel deliverables, timing of data drops and definitions of information purposes). More information about the items is included in the subsequent literature review section. Following the literature review, the paper conducts the comparison and discusses the findings.

\section{Literature Review}

Client requirements can be described in terms of the objectives, needs, wishes and expectations of the client (i.e., the person or firm responsible for commissioning the design and construction of a facility)" [6]. Client's requirements tend to evolve along the life cycle of the project either due to a change in the client requirements itself or due to adaption of the project to an unintended use [7]. Therefore a requirements management system is needed to cater for these evolving client's requirements. 
Requirements Management is also a well-researched area that has been applied to product development industries. "Requirements management is the process of eliciting, documenting, organizing, and tracking requirements and communicating this information across the various stakeholders and the project team" [8]. However much of these studies are not BIM related.

It was proposed that management of requirements should extend beyond elicitation and documentation and requires an approach that will enable changeability and impact analysis, accessibility, traceability and communication to all stakeholders [7]. It was further suggested that there should be a process for client's requirements information management across the whole life cycle and that the requirements and their impact should be tracked throughout whole life cycle of project including Facilities Management (FM) [7].

While project requirements are essential for the physical delivery of the project, with the recent advances in BIM and use of ICT in construction, the information requirements, which present a part of overall client's requirements, are gaining importance. Information is the key component of BIM and needs explicit attention in order to achieve the full potential of BIM across the whole life cycle. Therefore the EIR was introduced to address the information requirements and deliverables the client requires to make effective strategic and operational decisions across a project life cycle. One of the prominent EIR are those proposed in the UK by the BIM Task Group [9]. They include three areas of requirements with several items as illustrated in Table 1.

Table 1. EIR Guidance notes by BIM Task Group

\begin{tabular}{|c|c|c|}
\hline Technical & Management & Commercial \\
\hline $\begin{array}{ll}\text { 1. } & \text { Software Platforms } \\
\text { 2. } & \text { Data Exchange Format } \\
\text { 3. } & \text { Co-ordinates } \\
\text { 4. } & \text { Level of Detail } \\
\text { 5. } & \text { Training }\end{array}$ & $\begin{array}{ll}\text { 1. } & \text { Standards } \\
\text { 2. } & \text { Roles and } \\
\text { 3. } & \text { Responsibilities } \\
\text { Planning the work and } & \text { Data Segregation } \\
\text { 4. } & \text { Security } \\
\text { 5. } & \text { Coordination and Clash } \\
& \text { Detection process } \\
\text { 6. } & \text { Collaboration Process } \\
\text { 7. } & \text { Health and Safety and } \\
& \text { Construction Design } \\
\text { 8. } & \text { Management } \\
\text { 9. } & \text { Comptem Performance } \\
\text { 10. } & \text { Delivery Strategy for } \\
& \text { Asset Information }\end{array}$ & 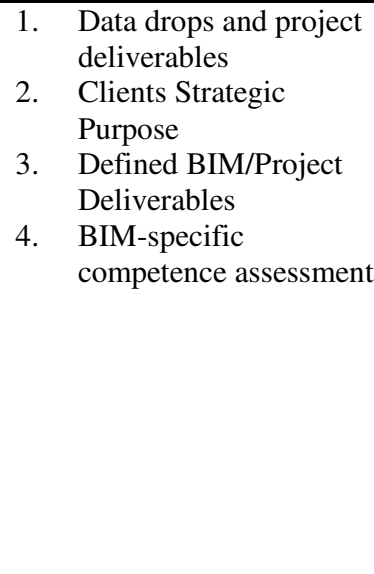 \\
\hline
\end{tabular}

To deliver the EIR, there are Publicly Available Specifications (PAS 1192-2:2013 [1], PAS 1192-3:2014 [10] and PAS 1192-5:2015 [11]), standards (BS 1192-2:2007 [12] and BS 1192-4:2014 [13] ), protocols (i.e. CIC BIM Protocol [14]), classification systems (Uniclass 2015) and technologies (the Digital Plan of Work) that are available for the entire UK construction industry. These specifications, standards, protocols, classification systems and technologies address various aspects of the application of BIM and related issues across the whole life cycle of a project. For example, the PAS 1192-2:2013 [1] specifies processes for information management for the capital/delivery phase of construction projects using BIM starting with Plane Language Questions (PLQ) to determine employer's/client's requirements through EIR and BIM Execution Plan (BEP) that specifies collaboration processes 
along the project life cycle, from the early design until the handover stage. Similarly CIC BIM Protocol [14] addresses issues regarding BIModels including the handling of intellectual property rights (IPR) and certain contractual requirements specific to BIModel at defined stages of projects.

BIM adoption is also increasing in Qatar and is being required by most of the major procurers (e.g. Ashghal, the Public Works Authority, Qatar Rail, Qatar Foundation, etc.). However, in Qatar there is a lack of EIR guidelines. This paper investigates the potential of delivering EIR by comparing current practice against the EIR of the UK BIM Task Group. The ultimate aim is to conduct a gap analysis and suggest recommendations for a Qatari-specific Employer Information Requirements (QEIR).

\section{Methodology}

This research adopted qualitative survey-based research approach. Surveys are designed to provide 'a snapshot of things are at a specific time' [15]. Surveys can be conducted using either questionnaires or interviews. This research combines a semistructured interview approach with the observation of secondary sources such as invitation to tender documentations. The interviews were conducted in two stages, starting from a less structured first stage to a more structured second stage. Six interviews were conducted in the first stage. The questions evolved during these initial interviews, resulting in a version restricted from further changes. The questions were still kept open ended to allow for interviewees' input beyond the given choices and examples of possible answers. The final version of the interview questions was used to interview additional 22 interviewees. Available invitation to tender documents were also collected and analyzed for getting relevant requirements. United Kingdom (UK) was selected as a benchmark as it is the only country where client's requirements are explicit and considered a cornerstone of the UK BIM policy.

The interviewees included stakeholders from Client $(9,32 \%)$, Contractor $(5,18 \%)$ and Consultant $(14,50 \%)$ organizations working on several ongoing projects in Qatar. The information gathered from the interviews was structured in a way that information can be compared against the areas and items of the UK EIR. Based on the comparison performed and inductive reasoning that caters for the special circumstances of Qatar construction industry (e.g. international companies of varying sizes, with origins from different parts of the world bringing their own perspectives) recommendations were made for a QEIR (Qatar Employer Information Requirements).

\section{Results}

Table 1, Table 2 and Table 3 summarize the results from the comparison against the items of the three EIR's Technical, Commercial and Management areas respectively. The EIR items, which were not addressed by the interviewees, are marked as N/A (Not Applicable). The comparison provided in the three tables is detailed and self-explanatory. The first column in each table indicates the item of the EIR which is the subject of investigation. The second column denotes the general requirements for that item as specified within the UK's EIR. The third column includes the finding about that item in Qatar. Finally, the fourth column provides 
evidence from the interviews that support the finding. The result from the comparison will be discussed in the next section where some general recommendations for QEIR are made.

Table 1: Technical items of EIR

\begin{tabular}{|c|c|c|c|}
\hline Item & $\begin{array}{c}\text { Employer } \\
\text { Information } \\
\text { Requirements } \\
\text { guideline UK } \\
\end{array}$ & $\begin{array}{c}\text { Client Information } \\
\text { Requirements in } \\
\text { Qatar }\end{array}$ & $\begin{array}{c}\text { Frequently } \\
\text { Reported issues } \\
\text { by Interviewees }\end{array}$ \\
\hline $\begin{array}{l}\text { Software } \\
\text { tools }\end{array}$ & $\begin{array}{l}\text { Should not be } \\
\text { Mandated except } \\
\text { those for } \\
\text { collaboration, } \\
\text { information } \\
\text { exchange and } \\
\text { Facility Management } \\
\text { Requirement }\end{array}$ & $\begin{array}{l}\text { Not prescribed in } \\
\text { most cases }\end{array}$ & $\begin{array}{l}\text { Difficulty in } \\
\text { exchanging } \\
\text { information due to } \\
\text { interoperability } \\
\text { issues. The use of } \\
\text { specific tools is } \\
\text { prescribed in some } \\
\text { projects.. }\end{array}$ \\
\hline $\begin{array}{l}\text { Data } \\
\text { Exchange } \\
\text { Format }\end{array}$ & $\begin{array}{l}\text { Define formats to } \\
\text { deliver data at data } \\
\text { drops }\end{array}$ & Mostly Specified & $\begin{array}{l}\text { Data Loss in } \\
\text { exchange }\end{array}$ \\
\hline Coordinates & $\begin{array}{l}\text { Adopt Common } \\
\text { Coordinate system } \\
\text { for spatial } \\
\text { coordination }\end{array}$ & $\begin{array}{l}\text { Specified using local } \\
\text { systems such as } \\
\text { Qatar National Grid } \\
\text { (QNG) and QND } \\
\text { (Qatar National } \\
\text { Datum }\end{array}$ & $\begin{array}{l}\text { Qatar National } \\
\text { Grid (QNG) and } \\
\text { QND (Qatar } \\
\text { National Datum } \\
\text { are used. }\end{array}$ \\
\hline $\begin{array}{l}\text { Level of } \\
\text { Detail / Level } \\
\text { of } \\
\text { Development }\end{array}$ & $\begin{array}{l}\text { Levels of Details to } \\
\text { be aligned with } \\
\text { Stages }\end{array}$ & $\begin{array}{l}\text { Required but } \\
\text { inconsistent with no } \\
\text { clear definition }\end{array}$ & $\begin{array}{l}\text { Lack of common } \\
\text { understanding } \\
\text { about what LODs } \\
\text { mean }\end{array}$ \\
\hline Training & $\begin{array}{l}\text { Specify Training } \\
\text { Requirements for } \\
\text { bidders and from } \\
\text { bidders }\end{array}$ & $\begin{array}{l}\text { Not Specified } \\
\text { explicitly. Mostly } \\
\text { Ad-Hoc. }\end{array}$ & $\begin{array}{l}\text { There is more } \\
\text { demand for BIM } \\
\text { training but limited } \\
\text { supply (training } \\
\text { providers) }\end{array}$ \\
\hline
\end{tabular}

Table 2: Commercial items of EIR

\begin{tabular}{|c|c|c|c|}
\hline Item & $\begin{array}{c}\text { Employer } \\
\text { Information } \\
\text { Requirements } \\
\text { guideline UK }\end{array}$ & $\begin{array}{c}\text { Client Information } \\
\text { Requirements in } \\
\text { Qatar }\end{array}$ & $\begin{array}{l}\text { Frequently Reported } \\
\text { Issues by Interviewees }\end{array}$ \\
\hline $\begin{array}{l}\text { Data drops } \\
\text { and project } \\
\text { deliverables }\end{array}$ & $\begin{array}{l}\text { Communicate } \\
\text { the content of } \\
\text { data drops and } \\
\text { their alignment } \\
\text { with work stages }\end{array}$ & Not clearly defined & $\begin{array}{l}\text { The information } \\
\text { deliverables or data } \\
\text { drops are not clearly } \\
\text { defined and cause } \\
\text { misunderstanding among } \\
\text { stakeholders. }\end{array}$ \\
\hline $\begin{array}{l}\text { Clients } \\
\text { Strategic } \\
\text { Purpose }\end{array}$ & $\begin{array}{l}\text { Communicate } \\
\text { the purpose of } \\
\text { Client's } \\
\text { information } \\
\text { requirements } \\
\text { and deliverables }\end{array}$ & $\begin{array}{l}\text { The existing } \\
\text { information } \\
\text { requirements do not } \\
\text { clearly state the } \\
\text { purpose for which it } \\
\text { will be used }\end{array}$ & $\begin{array}{l}\text { Clients require certain } \\
\text { BIM deliverables } \\
\text { without having clear } \\
\text { intention for those } \\
\text { deliverables }\end{array}$ \\
\hline
\end{tabular}




\begin{tabular}{llll}
\hline $\begin{array}{l}\text { Defined } \\
\text { BIM/Project } \\
\text { Deliverables }\end{array}$ & $\begin{array}{l}\text { Define BIM } \\
\text { Deliverables } \\
\text { aligned with } \\
\text { project work } \\
\text { stages }\end{array}$ & $\begin{array}{l}\text { BIM deliverables } \\
\text { are required but not } \\
\text { clearly defined. }\end{array}$ & $\begin{array}{l}\text { BIM deliverables are not } \\
\text { always realistic. } \\
\text { Different suppliers } \\
\text { interpret them differently } \\
\text { on what they need to } \\
\text { deliver and hence the } \\
\text { client does not receive } \\
\text { consistent information. }\end{array}$ \\
\hline $\begin{array}{l}\text { BIM-specific } \\
\text { competence } \\
\text { assessment }\end{array}$ & $\begin{array}{l}\text { Communicate } \\
\text { the competence } \\
\text { criteria for } \\
\text { bidders as part } \\
\text { of bid } \\
\text { submission }\end{array}$ & $\begin{array}{l}\text { Only relevant } \\
\text { experience is asked. }\end{array}$ & $\begin{array}{l}\text { Insufficient information } \\
\text { to objectively assess the } \\
\text { BIM competence }\end{array}$ \\
& & & \\
\hline
\end{tabular}

Table 3: Management items of EIR

\begin{tabular}{|c|c|c|c|}
\hline Item & $\begin{array}{l}\text { Employer } \\
\text { Information } \\
\text { Requirements } \\
\text { guideline UK }\end{array}$ & $\begin{array}{l}\text { Client Information } \\
\text { Requirements in } \\
\text { Qatar }\end{array}$ & $\begin{array}{l}\text { Frequently } \\
\text { Reported Issues } \\
\text { by Interviewees }\end{array}$ \\
\hline Standards & $\begin{array}{l}\text { Define BIM } \\
\text { standards } \\
\text { incorporated into } \\
\text { information } \\
\text { requirements }\end{array}$ & $\begin{array}{l}\text { There are no Qatari } \\
\text { specific BIM } \\
\text { standards. A } \\
\text { combination of } \\
\text { international } \\
\text { standards is used } \\
\text { and is often required } \\
\text { by contract. }\end{array}$ & $\begin{array}{l}64 \% \text { of } \\
\text { interviewees } \\
\text { reported BIM } \\
\text { standards are } \\
\text { required by } \\
\text { contracts. } \\
\text { Both clients and } \\
\text { suppliers have } \\
\text { different preference } \\
\text { for BIM standards } \\
\text { because of the } \\
\text { availability of } \\
\text { several standards } \\
\text { and their countries } \\
\text { of origin. }\end{array}$ \\
\hline $\begin{array}{l}\text { Roles and } \\
\text { Responsibilities }\end{array}$ & $\begin{array}{l}\text { Allocate roles } \\
\text { associated with the } \\
\text { management of the } \\
\text { model and project } \\
\text { information }\end{array}$ & $\begin{array}{l}\text { BIM specific roles } \\
\text { are required but both } \\
\text { role names and } \\
\text { responsibilities are } \\
\text { not consistently } \\
\text { used. }\end{array}$ & $\begin{array}{l}\text { Lack of industry } \\
\text { wide agreement } \\
\text { over the job } \\
\text { description of a } \\
\text { BIM Manager. The } \\
\text { job profile for BIM } \\
\text { managers is not } \\
\text { known. }\end{array}$ \\
\hline $\begin{array}{l}\text { Planning the } \\
\text { work and Data } \\
\text { Segregation }\end{array}$ & $\begin{array}{l}\text { Set out requirements } \\
\text { for the bidder's } \\
\text { proposals for the } \\
\text { management of the } \\
\text { modeling process }\end{array}$ & N/A & N/A \\
\hline Security & $\begin{array}{l}\text { Communicate Client } \\
\text { specific security } \\
\text { measures for data } \\
\text { security }\end{array}$ & N/A & N/A \\
\hline $\begin{array}{l}\text { Coordination } \\
\text { and Clash } \\
\text { Detection } \\
\text { process }\end{array}$ & $\begin{array}{l}\text { Define Coordination } \\
\text { process along with } \\
\text { quality control } \\
\text { requirements }\end{array}$ & $\begin{array}{l}\text { Coordination or } \\
\text { clash detection is } \\
\text { used on almost all } \\
\text { BIM projects. }\end{array}$ & $\begin{array}{l}71 \% \text { of } \\
\text { interviewees } \\
\text { reported use of } \\
\text { software for }\end{array}$ \\
\hline
\end{tabular}




\begin{tabular}{|c|c|c|c|}
\hline & & & $\begin{array}{l}\text { coordination and } \\
\text { clash detection }\end{array}$ \\
\hline $\begin{array}{l}\text { Collaboration } \\
\text { Process }\end{array}$ & $\begin{array}{l}\text { Define how, where } \\
\text { and when } \\
\text { information will be } \\
\text { shared }\end{array}$ & $\begin{array}{l}\text { Not available and } \\
\text { clearly defined } \\
\text { across the industry }\end{array}$ & $\begin{array}{l}29 \% \text { of } \\
\text { interviewees } \\
\text { reported use of } \\
\text { BIM protocols for } \\
\text { collaboration. }\end{array}$ \\
\hline $\begin{array}{l}\text { Health and } \\
\text { Safety and } \\
\text { Construction } \\
\text { Design } \\
\text { Management }\end{array}$ & $\begin{array}{l}\text { Define how BIM } \\
\text { based working will } \\
\text { support H\&S and } \\
\text { Construction Design } \\
\text { Management. }\end{array}$ & $\begin{array}{l}\text { There are specific } \\
\text { requirements in } \\
\text { Qatar Construction } \\
\text { Standards (2014) but } \\
\text { are not related to } \\
\text { BIM }\end{array}$ & N/A \\
\hline $\begin{array}{l}\text { System } \\
\text { Performance }\end{array}$ & $\begin{array}{l}\text { Communicate } \\
\text { employer's } \\
\text { requirements for IT } \\
\text { and systems } \\
\end{array}$ & N/A & N/A \\
\hline $\begin{array}{l}\text { Compliance } \\
\text { Plan }\end{array}$ & $\begin{array}{l}\text { Communicate } \\
\text { requirements for } \\
\text { model integrity and } \\
\text { other data sources }\end{array}$ & N/A & N/A \\
\hline $\begin{array}{l}\text { Delivery } \\
\text { Strategy for } \\
\text { Asset } \\
\text { Information }\end{array}$ & $\begin{array}{l}\text { Define information } \\
\text { exchange standard } \\
\text { for asset information } \\
\text { and obtain proposals } \\
\text { with regards to asset } \\
\text { information delivery } \\
\text { to employer Facility } \\
\text { Management } \\
\text { environment }\end{array}$ & $\begin{array}{l}\text { Insufficiently } \\
\text { defined or absent } \\
\text { requirements for } \\
\text { asset or facility } \\
\text { management } \\
\text { information }\end{array}$ & $\begin{array}{l}\text { Respondents } \\
\text { indicated lack of } \\
\text { BIM requirements } \\
\text { for Facilities } \\
\text { management; } \\
\text { COBie is required } \\
\text { in some cases but } \\
\text { there is a lack of } \\
\text { understanding of } \\
\text { how FM systems } \\
\text { can be populated } \\
\text { with that consumes } \\
\text { COBie data }\end{array}$ \\
\hline
\end{tabular}

\section{Discussion and Recommendations}

The key distinguishing factors between the EIR guidelines of the UK and BIM current practice in Qatar are in the degree of completeness or coverage of items; the clarity and consistency in the definition of EIR items, and the project stage in which requirements are embedded. In the UK, the PAS 1192-2 requires that design team and contractor team include an outline BIM Execution Plan (BEP) in their proposals at the pre-contract stage to demonstrate their approach to deliver the EIR [1]. After the award of the contract, the responsible supply chain needs to develop a detailed BIM execution plan aligned with the EIR.

The EIR items that are included in tender documents in Qatar mainly address a few items of each of the EIR's areas. However, such items are not consistently prescribed and are often interpreted differently by the various project stakeholders.

Under the technical items of the EIR, the Level of Details (LOD) is specified without referring to a specific methodology which sets the incremental development of the LODs. LODs are also often misunderstood by some suppliers or mandated on specific trades (e.g. architectural and structural) involved in a construction project. Software tools are generally not prescribed. However, some large scale projects 
specify the use of certain design authoring tools and collaboration networks. There are no data exchange format (i.e. neutral format) prescribed across the whole industry but these are usually specified within the protocols developed by the lead consultant or contractor on project. Much of the large-scale projects in Qatar require IFC (Industry Foundation Classes) and 3dPDF.

Within the commercial area of the EIR, BIM capability of organizations is assessed at the pre-qualification phase although they are no standards for BIM capability assessment. It is often assessed based on the number of previous BIM projects undertaken by the suppliers. There are no requirements for the generation of BIM data drops or specific datasets at certain work stages. Several work stages are adopted within Qatar's construction industry including the RIBA Plan of Work, the AIA Phases of Work, and their modified versions by large procurers such as Ashghal (Public Work Agency). The respondents reported circumstances where suppliers working on the same project referred to different project work phases resulting in conflicts and issues that affected the progress of projects.

Under the management area of the EIR, similarly to the project work phases, a combination of standards, protocols and specifications (BS 1192-2, PAS 1192-2, AIA BIM protocols, etc.) are adopted depending on the country of origin of the lead consultant or contractor. Some BIM deliverables such as design coordination (clash avoidance) and 4D and 5D planning are increasingly specified. There are increasing number of projects which require production and site drawings to be produced out of a coordinated model. Also, site inspections, and the consequent authorization of payment, are increasingly conducted within and linked 5D environments. There are no agreed upon definition of BIM roles and their responsibility. The role that is often required by contracts is the "BIM Manager". Finally, there are no clear BIM requirements for the delivery of data to the facility management phase.

The definition of EIR as early as possible in projects, their shared understanding among the supply chain, and the implementation of protocols to deliver them, are key principle for achieving a whole life cycle approach in construction projects. It is clear from the comparison that a whole life cycle approach in Qatar's construction industry is currently not possible. However, in each of the areas of EIR (technical, commercial and management), Qatar's construction industry exhibits capabilities in several items. To build upon current capabilities and build the foundation for the industry to start moving towards a more diffused and mature adoption of BIM, there is a need to develop Qatar Employer Information Requirements (QEIR). The QEIR may require adjustments depending on asset type, project stages, project needs, procurements strategy, IT requirements, terminology, and detailed technical information requirements.

This is also important as several large employers and clients have started in recent year hiring consultants to define their EIR and roll them out on their projects as it was observed during the interviews. Over time this will result in several competing commercial, technical and management requirements. Therefore, regarding the general requirements for the definition of guidelines for QEIR, it is important to ensure that they:

- Are adequately generic so that can be adopted across different projects and employers and are un-biased towards current technologies or/and processes;

- Are defined based on sufficient knowledge of employer's internal processes;

- Are related roles and responsibilities at employer's organization or agree on a specific changes to current roles;

- Build up a BIM team at employer's side to supervise the EIR compliance; 
- Consider applicable standards in Qatar, e.g. QCS and to evaluate the applicability of international BIM/information standards;

- Clarify the interactions with other management systems within employer organizations;

- Clarify model ownership and intellectual property issues, and

- Include definition of BIM related terminologies to avoid misunderstanding among project stakeholders.

In addition to above general guidelines, a self-explanatory list of recommendations is included in Table 4, Table 5 and Table 6 representing specific recommendations for the items of the three areas of EIR Guidelines.

Table 4: Recommendations for the technical area of the QEIR

\begin{tabular}{|c|c|}
\hline Item & Recommendations \\
\hline $\begin{array}{l}\text { Software } \\
\text { Platforms }\end{array}$ & $\begin{array}{l}\text { Should not be dictated by the employer unless the project is at later stage and } \\
\text { models are already produced in specific software tools. However as the } \\
\text { employers in Qatar are often dealing with multiple mega projects, a clear } \\
\text { strategy is required to clarify how to deal with deliverables prepared in various } \\
\text { software packages. Viewer software at employer's offices may require specific } \\
\text { exports format too. At minimum software should be clarified in contractor's } \\
\text { BEP and is subject of approval. The employer's choice of document } \\
\text { management system (DMS) should be communicated to the supply chain to } \\
\text { get consistent and seamless submissions. }\end{array}$ \\
\hline $\begin{array}{l}\text { Data Exchange } \\
\text { Format }\end{array}$ & $\begin{array}{l}\text { Beside the native format, neutral data formats should be made available such } \\
\text { as IFC or PDF. However the information content in case of IFC should be } \\
\text { verified. As several projects are infrastructure and utilities, the Centre for } \\
\text { Geographic Information Systems (CGIS) needs should be considered in the } \\
\text { QEIR. }\end{array}$ \\
\hline Co-ordinates & $\begin{array}{l}\text { Qatar National Grid (QNG) and QND (Qatar National Datum), origin and } \\
\text { units as a minimum }\end{array}$ \\
\hline Level of Detail & $\begin{array}{l}\text { Level of Detail for geometry (LOD) and Level of Information (LOI) including } \\
\text { clarification on evolution along the project work phases. A model element } \\
\text { matrix should be requested for all project phases to describe LOD and LOI in } \\
\text { more detail. LOD should be defined to serve the purpose of models as } \\
\text { unnecessary detailed geometry will affect the performance. LOI should be also } \\
\text { planned carefully to serve decisions along the project work phases and the } \\
\text { O\&M requirements. }\end{array}$ \\
\hline Training & $\begin{array}{l}\text { Areas of training covering different types of competencies should be specified } \\
\text { and suppliers should demonstrate their training plan in these areas. }\end{array}$ \\
\hline
\end{tabular}

Table 6: Recommendations for the commercial area of the QEIR

\begin{tabular}{ll}
\hline Item & Recommendation \\
\hline $\begin{array}{l}\text { Data drops and } \\
\text { project } \\
\text { deliverables }\end{array}$ & $\begin{array}{l}\text { It is recommended to clearly define deliverables at specific data drops. The } \\
\text { latter should be also aligned with project stages and linked to other projects } \\
\text { deliverables. It should be also made clear which employer's processes the BIM } \\
\text { deliverables are supporting at each stage. A pre submission presentation or } \\
\text { workshop can facilitate and speed up the approval process. }\end{array}$ \\
\hline $\begin{array}{l}\text { Clients Strategic } \\
\text { Purpose }\end{array}$ & $\begin{array}{l}\text { The overall purpose of the employer mandating BIM should be made clear in } \\
\text { the contract. Also the purpose of each required BIM process should be } \\
\text { addressed. This will help contractors/consultant to understand the scope and } \\
\text { utilization of their deliverables. }\end{array}$ \\
\hline $\begin{array}{l}\text { BIM-specific } \\
\text { competence }\end{array}$ & $\begin{array}{l}\text { There is a need to develop a competency based system for the BIM roles (e.g. } \\
\text { BIM Manager) in Qatar and a system to assess the BIM capability of } \\
\text { assessment }\end{array}$ \\
organization. QEIR could require the project staff and their organizations with \\
this system. .
\end{tabular}


Table 5: Recommendations for the management area of the QEIR

\begin{tabular}{|c|c|}
\hline Item & Recommendations \\
\hline Standards & $\begin{array}{l}\text { There is a need to develop BIM standards/guidelines and protocols for Qatar's } \\
\text { construction industry. Such standards should be structured by BIM use. A } \\
\text { suitable classification system should be adopted. National BIM protocols or } \\
\text { BIM Execution Protocols (BEP) and templates should be developed. Also the } \\
\text { codifications/naming dictated by specific standards at file level should be } \\
\text { compared with existing CAD and documents naming defined in DMS in case } \\
\text { there is no overall information requirements established. This is very } \\
\text { important in large scale projects. }\end{array}$ \\
\hline $\begin{array}{l}\text { Roles and } \\
\text { Responsibilities }\end{array}$ & $\begin{array}{l}\text { Specific roles and responsibilities related to BIM should be included in the } \\
\text { QEIR. Minimum qualification and experience in previous projects for the key } \\
\text { BIM personnel is also recommended. A role specific assessment system for } \\
\text { assessing BIM personnel should be developed. }\end{array}$ \\
\hline $\begin{array}{l}\text { Planning the work } \\
\text { and Data } \\
\text { Segregation }\end{array}$ & $\begin{array}{l}\text { The EIR should clarify model management, folder structure and collaboration } \\
\text { environment (Common Data Environments) according to project needs. It is } \\
\text { recommended to define how and when models and information will be } \\
\text { published to the employer. This should reflect the employer's DMS and } \\
\text { internal processes, review, monitoring and reporting periods. } \\
\text { In mega projects, where several contractors are involved, it is important that } \\
\text { the QEIR defines a common model breakdown and clear zoning strategy. }\end{array}$ \\
\hline Security & $\begin{array}{l}\text { Depending on how information will be published to employer, security } \\
\text { requirements should be included. There could be special security for certain } \\
\text { data with high level of confidentiality and the importance. }\end{array}$ \\
\hline $\begin{array}{l}\text { Coordination and } \\
\text { Clash Detection } \\
\text { process }\end{array}$ & $\begin{array}{l}\text { The QEIR should require the specification of software involved, clash matrix } \\
\text { and settings at different stages, the coordination process workflow including } \\
\text { frequency, meetings and client presentations. Also the description of quality } \\
\text { procedure and the reporting on clash status should be requested as part of } \\
\text { QEIR. }\end{array}$ \\
\hline $\begin{array}{l}\text { Collaboration } \\
\text { Process }\end{array}$ & $\begin{array}{l}\text { Mandate that suppliers adopt a Common Data Environment (CDE) and define } \\
\text { how information will be managed among them and shared with the employer }\end{array}$ \\
\hline $\begin{array}{l}\text { Health and Safety } \\
\text { and Construction } \\
\text { Design } \\
\text { Management }\end{array}$ & $\begin{array}{l}\text { It is recommended to collect H\&S related information at defined data drops. } \\
\text { Specific presentations could be requested to clarify safety issues or resolutions } \\
\text { strategies with BIM support. }\end{array}$ \\
\hline $\begin{array}{l}\text { System } \\
\text { Performance }\end{array}$ & $\begin{array}{l}\text { Employers could make restrictions according to their specific in house } \\
\text { applications, e.g. model size and formats, software and versions and model } \\
\text { viewer capabilities. }\end{array}$ \\
\hline Compliance Plan & $\begin{array}{l}\text { QA/QC procedures should be mandated to ensure quality of information and } \\
\text { models. }\end{array}$ \\
\hline $\begin{array}{l}\text { Delivery Strategy } \\
\text { for Asset } \\
\text { Information }\end{array}$ & $\begin{array}{l}\text { This area has not been addressed with adequate details in the interviews. It } \\
\text { was only identified that COBie is mandated on many projects in Qatar. COBie } \\
\text { could be used as a data structure to convey data for the O\&M Phase. However, } \\
\text { it respondents in Qatar reported interoperability issues with their FMS and } \\
\text { lack of understanding in this area. }\end{array}$ \\
\hline $\begin{array}{l}\text { Management } \\
\text { Instruments }\end{array}$ & $\begin{array}{l}\text { Further management instruments should be addressed, especially drawings and } \\
\text { models registers that should be submitted regularity to show status. Also clear } \\
\text { strategies on how to progress model elements between project phases - i.e. } \\
\text { design, construction and as built, including ownership - is required. }\end{array}$ \\
\hline Processes & $\begin{array}{l}\text { Further BIM supported processes e.g. progress monitoring, payments } \\
\text { procedures, cost control, interface management, site logistics, etc. should be } \\
\text { addressed in the QEIR. }\end{array}$ \\
\hline
\end{tabular}




\section{Conclusion and Limitations}

This paper analyzed the potential of delivering EIR in Qatar using the EIR guidelines of the UK BIM Task group. The results showed that the construction industry in Qatar has certain capabilities in several items under each of the three areas of EIR (technical, commercial, management). However, there are significant challenges related to the lack of Qatari-specific BIM standards, BIM dictionary, project work phases, capability assessment, etc. Based on the gap analysis conducted, the research suggested the development of Qatar Employer Information Requirements (QEIR) and some recommendation for its various items.

The limitation of this study is related to the inconsistent coverage of all items of EIR in the interviews. Also the interviews were conducted with relatively large organizations working on large projects. Therefore, the results of the study may be skewed towards larger stakeholders, which however, represent the largest share of the Qatari construction market.

Finally, the outcomes from this research aim to instigate Qatar's construction industry stakeholders to work towards the development of QEIR by proposing this seed of recommendations as the starting point for this discussion.

\section{Acknowledgement}

The work described in this publication was part of the research project funded by the National Priority Research Program NPRP No.: 6 - 604 - 2 - 253.

\section{References}

[1] BSI, "PAS 1192-2:2013 Specification for information management for the capital / delivery phase of construction projects using building information modelling," 2013.

[2] J. M. Kamara, C. J. Anumba, and N. F. O. Evbuomwan, "Process model for client requirements processing in construction," Bus. Process Manag. J., vol. 6, no. 3, pp. 251-279, 2000.

[3] S. T. Kometa and P. O. Olomolaiye, "Evaluation of Factors Influencing Construction Clients' Decision to Build," J. Manag. Eng., vol. 13, no. 2, pp. 77-86, 1997.

[4] B. Succar and M. Kassem, "Macro-BIM adoption: Conceptual structures," Autom. Constr., vol. 57, pp. 64-79, 2015.

[5] Kassem, M., Succar, B., and Dawood, N. (2015) Building Information Modeling: Analyzing Noteworthy Publications of Eight Countries Using a Knowledge Content Taxonomy, in R.R.A. Issa, and S. Olbina (eds), Building Information Modeling: Applications and Practices, American Society of Civil Engineers, Reston, Virginia, pp. 329-371.. 
[6] J. M. Kamara and C. J. Anumba, "Client Requirements Processing for Concurrent Life-Cycle Design and Construction," Concurr. Eng., vol. 8, no. 2, pp. 74-88, 2000.

[7] A. K. Jallow, P. Demian, A. Baldwin, and C. Anumba, "Life cycle approach to requirements information management in construction projects: State-ofthe-art and future trends," Assoc. Res. Constr. Manag. ARCOM 2008 - Proc. 24th Annu. Conf., vol. 2, pp. 769-778, 2008.

[8] "Office of Government Commerce, UK. Requirements Management. Available

[http://www.ogc.gov.uk/delivery_lifecycle_requirements_management.asp].”

[9] BIM Task Group, "Employer's Information Requirements Core Content and Guidance Notes,” 2013.

[10] BSI, "PAS1192-3:2014 Specification for information management for the operation phase of assets using building information modelling," no. 1, 2014.

[11] BSI, "PAS 1192-5:2015 Specification for security-minded building information modelling, digital built environments and smart asset management," 2015.

[12] BSI, "BS 1192 : 2007 Collaborative Production of Architectural, Engineering and Construction Information - Code of practice," 2007.

[13] BSI, "BS 1192-4:2014 Collaborative production of information Part 4 : Fulfilling employer' $s$ information exchange requirements using COBie Code of practice," 2014.

[14] Construction Industry Council, "BUILDING INFORMATION MODEL (BIM) PROTOCOL,” 2013.

[15] D. Martyn, "The Good Research Guide - for small-scale social research projects," p. 358, 2007. 